\title{
Lessons from NATO's Military Missions in the Western Balkans
}

\author{
Dennis Blease *
}

\section{Introduction}

The subject of learning lessons is fraught with difficulties, not least because lessons, like beauty, are often in the eye of the beholder. It has been the author's experience that many lessons that are formally identified as such are not learned. The reasons for this are varied: those identifying the lessons may be biased; the resources to enable learning may be lacking; and the lessons simply may not "stick." Nonetheless, those lessons that do become embedded in the human and organizational psyche are those that have created new doctrines, reshaped institutions, become an integral part of new training standards, and demonstrably shown an improvement in the conduct of business.

NATO's involvement in the Western Balkans over the past fifteen years has provided a rich vein of experience and has fomented considerable change. This article examines that experience and analyzes some of the major lessons that have been identified. Some will have been learned, while others have not; in some instances, the lessons that were identified will subsequently prove to be flawed. Throughout this analysis the paper will attempt to chart the metamorphosis of NATO from a passive Cold War military alliance to an active political and security actor on the world stage.

\section{Different Security Challenges Demand Different Approaches and Different Structures}

Chris Donnelly suggests that the nature of armed conflict and our response to new threats changes fundamentally only every fifty years. ${ }^{1}$ This change may not be attributable to one single cause, but rather a combination, such as changes in weapons technology (for example, the introduction of nuclear weapons) or a change in the balance of world power. This latter example was undoubtedly the case at the turn of the twentyfirst century with the end of the bi-polar security system of the Cold War.

Another key change, however, has taken place in our perception of security. During the Cold War, "the terms 'defence' and 'security' were nearly synonymous." 2 Large

\footnotetext{
Dennis Blease is a retired British Army flag officer who has served in the Western Balkans with NATO, the UN, and the EU. He is currently Deputy Director of the Centre for Security Sector Management at Cranfield University.

1 Christopher Donnelly, "Security in the 21st Century: New Challenges and New Responses," in NATO and New International Relations, ed. Dr. Lidija Čehulić (Zagreb: Atlantic Council of Croatia \& Political Culture Publishing and Research Institute, 2004), 24-26.

2 Dr. Jan Arveds Trapans, "Security Sector Reform in Central and Eastern Europe: The Work of Civilians and the Military," 4 (Groningen: Centre for European Security Studies, 2000); available at www.dcaf.ch/legal_wg/ev_geneva_00_SSR_Trapans.pdf.
} 
standing armies, territorial defense, and hard geographical lines of confrontation characterized the geostrategic situation before 1989. This is no longer the case for most countries in the Euro-Atlantic region, where security is primarily "measured in nonmilitary terms and threats to security are non-military in nature." ${ }^{3}$ In addition, there has been a growing recognition that security is also central to effective and sustainable development. In 2004, the U.K.'s Minister for International Development said at the Center for Global Development, "development without security is not possible; security without development is only temporary." 4

It was, however, the disintegration of Yugoslavia, with all its attendant human suffering, that proved to be the catalyst for much change within NATO. This event was not only pivotal in reshaping the Alliance's perceptions of security, but also the way in which it was delivered. In essence, NATO demonstrated the "ability to help countries to transition from [being] security consumers to security providers." ${ }^{5}$ The Cold War version of NATO would have been unable to perform a useful role in the Western Balkans over the past fifteen years, or indeed in present-day Afghanistan. Thus we have seen the transformation of NATO from an unused military tool in 1989 to a politicomilitary organization that now has some 112,000 troops deployed on operations. Similarly, the emergence of the EU's own defense and security ambitions and its military deployment into the Western Balkans has mirrored this shift in structure and approach. ${ }^{6}$ As the change management business guru, Alan Deutschman, would say, "Change or Die." 7 One could therefore successfully argue that a key lesson from NATO's military involvement in the Western Balkans has been the acceptance of the need to fundamentally adapt to a changed and unfamiliar security environment; this is a process that continues today. ${ }^{8}$ Let us now turn to those military interventions and attempt to identify the relevant lessons.

3 Donnelly, "Security in the 21st Century," 27. For some empirical data taken from Kosovo on public perceptions of security, see Anthony Cleland Welch, Sokol Kondi, Dana Stinson, and Michael von Tangen Page, eds., Kosovo Internal Security Sector Review (Pristina: United Nations Development Program, 2006), 18-23; available at www.kosovo.undp.org/repository/ docs/ISSR_report_eng_ver2.pdf.

4 Hilary Benn, "A Shared Challenge: Promoting Development and Human Security in Weak States," speech delivered at the Center for Global Development, Washington, D.C. (23 June 2004); text available at www.cgdev.org/doc/weakstates/WeakStates_Benn.pdf.

5 “NATO's Agenda: Key Issues Facing the Bucharest Summit," RÜSI Occasional Paper (1 April 2008); available at www.rusi.org/downloads/assets/Final_Report_English.pdf.

6 This type of "paradigm shift" was highlighted by Rupert Smith in The Utility of Force: The Art of War in the Modern World (New York: Knopf, 2007), 4.

7 Alan Deutschman, Change or Die: The Three Keys to Change at Work and in Life (New York: HarperBusiness, 2007).

8 NATO Secretary-General Anders Fogh Rasmussen, "NATO Transformation and Reform Vital to Facing New Challenges," speech delivered at the Belgian Royal High Institute for Defense (26 April 2010); available at www.nato.int/cps/en/natolive/opinions_62923.htm. 


\section{Military Interventions in the Western Balkans}

The initial stages of NATO's military involvement in the Western Balkans during the early 1990s did not augur well for the mission's success. Notwithstanding a confused and ambiguous UN mandate, several European NATO members decided to support the UN peacekeeping mission with ground troops. ${ }^{9}$ But domestic and economic difficulties within a number of NATO countries, plus a genuine concern about potential casualties, meant that this support was less than whole-hearted. Fundamentally, most Allies did not believe that a conflagration in South East Europe had any direct bearing on their national interest. Thus NATO, as an organization, did little to confront the growing crisis on the borders of its traditional Euro-Atlantic area. Joyce Kaufman argues that, "In retrospect, one of the lessons of Bosnia for NATO is the realization that as an Alliance of sovereign nations, NATO cannot take action unless or until there is pressure to do so and the member states perceive that it is in their political interest to do so." 10

\section{Bosnia}

It was only after three years of political prevarication that the NATO Allies faced up to the dangers of the Balkan wars. A combination of the genocide at Srebrenica and the mortar attack on shoppers in the Markale Market in Sarajevo in the summer of 1995 prompted the Alliance to tackle the unfolding humanitarian and security disaster. The subsequent bombing campaign by NATO against the Serbs in August and September 1995 eventually brought everybody back to the negotiating table. As Christopher Meyer explains, "It was a classic exercise in diplomacy backed by force." ${ }^{11}$ It was a lesson that NATO learned in Bosnia and had to re-learn in Kosovo. The resultant Dayton Peace Accords allowed for a NATO Implementation Force (IFOR) to be deployed in December 1995, but even then several European member states insisted that they would not maintain ground troops in Bosnia without the participation of the United States. It would be overly simplistic to say that NATO's reluctance to become directly involved in ground combat operations throughout the period 1992-95 was due to the uncertainties of U.S. engagement, but it was undoubtedly a factor. As Dana Allin points out,

Paris, London and other European capitals were determined never again to deploy ground troops in Bosnia while Washington, in their view, indulged a rhetorical idealism,

9 UNPROFOR took on the task of delivering humanitarian relief to civilians in Bosnia under a limited peacekeeping mandate, although there was no peace agreement. For a full treatment, see David Owen, Balkan Odyssey (New York: Harcourt Brace, 1995). For a briefer account, see John Stremlau, People in Peril: Human Rights, Humanitarian Action and Preventing Deadly Conflict (Washington, D.C.: Carnegie Commission on Preventing Deadly Conflict, 1998), 29-31.

10 Joyce Kaufman, NATO and the Former Yugoslavia: Crisis, Conflict, and the Atlantic Alliance (Lanham, MD: Rowman \& Littlefield, 2002), 217.

11 Christopher Meyer, Getting Our Way: 500 Years of Adventure and Intrigue: the Inside Story of British Diplomacy (London: Weidenfeld \& Nicolson, 2009), 253. 
with no American lives at risk, and was careless about working at cross purposes with what the Europeans were trying to establish. ${ }^{12}$

This, then, became a lesson that was identified by the European Allies, and was in the forefront of their thinking in the run-up to the Kosovo crisis.

\section{Kosovo}

This prelude may not have been as bloody as that in Bosnia, but it was every bit as predictable. In his book on the history of Kosovo, Noel Malcolm refers to the oftquoted saying that the "Yugoslav crisis started in Kosovo and will end in Kosovo"13 as one of the few things on which all parties to the Balkans Wars can agree. There were many criticisms of the Dayton Peace Accords, but perhaps the most significant was that it did not tackle the issue of Kosovo. It could be argued that this was because the question was too contentious but, by sidestepping the problem, it was merely storing up trouble for a future date. History repeated itself in 1999 with the adoption of UN Security Council Resolution 1244, which put off a decision on Kosovo's future status, and effectively left a time bomb that continues to tick today. ${ }^{14}$ This is a lesson that was clearly not learned. Others also argue that the lesson of Dayton for the Kosovar Albanians was that "only the application of force to achieve self-determination could secure the top-level attention of the West." ${ }^{15}$ The extent to which this view was accepted would seriously weaken the arguments of those who sought a peaceful solution to the crisis.

Although the Kosovo Liberation Army (KLA) was barely functional in the early spring of 1996, it had grown weary of Rugova's non-violent approach, and began to ramp up the scale of its violent attacks on the Serbian authorities. By the end of 1997, helped by an enormous influx of weapons from neighboring Albania, ${ }^{16}$ the crisis had increased dramatically, and the death toll had risen on both the ethnic-Serb and ethnicAlbanian side. ${ }^{17}$ It was not until March 1998, when the Serb special police killed over eighty ethnic Albanians in an attack on the family compound of Adem Jashari, that the violence "turned [from] an armed resistance movement into a province-wide insurrection." 18 Eventually, the "scorched earth" policy of Milošević (and the resultant flood of

12 Dana Allin, NATO's Balkan Interventions (London: International Institute for Strategic Studies, 2002), 40.

13 Noel Malcolm, Kosovo: A Short History (New York: Harper Perennial, 1999), 65.

14 The UN Secretary-General's Special Envoy for Kosovo's Future Status, President Martti Ahtisaari, produced a set of "Comprehensive Proposals" for the province in March 2007 that would have given Kosovo a form of "supervised independence." Unfortunately, the proposals have remained blocked in the Security Council ever since, although a well-coordinated declaration of independence was issued by the Kosovo Assembly on 17 February 2008.

15 Tom Gallagher, The Balkans in the New Millennium: In the Shadow of War and Peace (London: Routledge, 2005), 34.

16 Ibid., 35-37.

17 For a more detailed treatment of the crisis, see Malcolm, Kosovo, 652-59.

18 Allin, NATO's Balkan Interventions, 51. 
refugees) galvanized NATO into a consensus over action. Authority was given to SACEUR in October 1998 to launch air strikes against Yugoslavia.

The bombing was only averted by a last-minute compromise and the creation of the OSCE-led Kosovo Verification Mission (KVM) ${ }^{19}$ It is not within the scope of this paper to expand on events in the winter of 1998-99, except to say that after abortive peace talks in Rambouillet, near Paris, in early 1999, and a resumption of ethnic cleansing by Serb forces, some three quarters of a million refugees fled over the border to Macedonia, Albania, and Montenegro. It was apparent to NATO that this was ethnic cleansing on a grand scale. As the U.S. envoy Christopher Hill said, "We did not go to war over Rambouillet. We went to war because [Milošević] started ethnic cleansing. He sent in 40,000 troops to intimidate the Albanians and to intimidate us." ${ }^{20}$

The result was that NATO began to bomb targets in the former Yugoslavia on the evening of 24 March 1999. The bombing continued for eleven weeks. On 9 June, NATO signed a Military Technical Agreement with the Yugoslav military, and on the following day UN Security Council Resolution 1244 was passed in New York, effectively making Kosovo a "ward of the international community.",

The euphoric return of the Kosovar refugees rapidly overtook the more cautious advance by NATO ground troops. The euphoria did not last long, as retribution against the minority Serb population of Kosovo was swift. Allin comments that "the tide of revenge went more or less unchecked in a security vacuum that NATO military forces were unable to fill." 22 This was in part due to the configuration of the ground forces, which were prepared for warfighting, not peacekeeping. But it was also due to an unwillingness on the part of NATO forces to engage in what appeared to be civil tasks, because the mandate of the mission did not explicitly include any responsibility for rule of law or law enforcement. NATO was charged with providing a "safe and secure environment"; the international civilian presence (UN Mission in Kosovo, or UNMIK) was tasked with maintaining civil law and order. ${ }^{23}$ It soon became clear that NATO's problems had only just begun with the successful deployment of troops into Kosovo. We shall return to the rule of law issue later in this article.

The justification for the Kosovo intervention bears some further discussion. Notwithstanding the plethora of UN Security Council resolutions regarding the province up until September 1998, this changed with a threat from the Russian Foreign Minister to veto any resolution that sought to authorize the use of force in Kosovo. Paul Heinbecker, Canadian Permanent Representative to the UN during the Kosovo crisis, said

19 Some background on the genesis and role of the KVM and its controversial head, William Walker, can be found in Gallagher, The Balkans in the New Millennium, 42-43.

20 Briefing by Christopher Hill in Ohrid, Macedonia, July 1999, as quoted in Allin, NATO's Balkan Interventions, 60.

21 Iain King and Whit Mason, Peace at Any Price: How the World Failed Kosovo (Ithaca, NY: Cornell University Press, 2006), 49.

22 Allin, NATO's Balkan Interventions, 71.

23 For the text of UN Security Council Resolution 1244, see http://www.unmikonline.org/ UNMIKONLINE2009/1244resolution.htm. 
that "the most striking and significant feature of Security Council decision making on Kosovo was its absence, at least in the crucial winter and spring months of 1999." ${ }^{24}$

The decision by the NATO member states effectively to bypass the Security Council carried three significant lessons. First, by removing the UN from the decision-making process, it demonstrated that, "if the Security Council proves to be an obstacle to action ... [then it] ... can and will be bypassed"; the situation in Kosovo "illustrate[d] both the feasibility of protecting the vulnerable and the limits of the veto." ${ }^{25}$ The downside of this lesson might be that the U.S. and its "coalition of the willing" believed that success in operating outside the aegis of the UN in Kosovo in 1999 could translate into similar success in Iraq in 2003. Unfortunately, the former had established credible legitimacy, while the latter never did. The second lesson was that eventually the international community was required to return to the UN in order achieve a resolution and for the UN to take responsibility for a civilian presence in Kosovo. The lack of involvement of the UN until the resolution was passed posed significant resource and practical problems for UNMIK, from which it never really recovered. The third lesson is that the humanitarian casus belli promoted by the British Prime Minister ${ }^{26}$ spawned a wave of literature arguing the simple idea that a state has a "responsibility to protect" its citizens, and that states should be held to account by the international community if they fail to do so. ${ }^{27}$

NATO had explicitly stated that Alliance unity was the center of gravity of the Kosovo operation. In the long term this was maintained, but there were several close calls. During the bombing campaign, several NATO members (including the U.S.) refused to commit ground forces to a possible land operation. In the case of the U.S. government, they were subject to legislative challenges from both the Senate and the House of Representatives to the potential deployment of U.S. troops. ${ }^{28}$ This reluctance undoubtedly provided sustenance to the Milošević regime, and bolstered the hope "that it might ride out the air campaign until NATO's consensus, presumed to be wobbly,

24 Paul Heinbecker, "Kosovo," in The UN Security Council: From the Cold War to the 21st Century, ed. David Malone (Boulder, CO: Lynne Rienner, 2004), 537.

25 Ibid., 538.

26 Tony Blair, "Doctrine of the International Community," speech delivered to the Economic Club of Chicago (24 April 1999); available at www.number10.gov.uk/archive/2003/01/ doctrine-of-the-international-community-2441999-1297.

27 For example, see Gareth Evans, The Responsibility to Protect: Ending Mass Atrocity Crimes Once and for All (Washington, D.C.: Brookings Institution Press, 2008). The term "responsibility to protect" is often abbreviated to R2P or RTP. See also www.responsibilitytoprotect.org.

28 For more discussion, see Kaufman, NATO and the Former Yugoslavia, 194-95. One of the little-known impacts of this debate was that U.S. personnel in NATO's HQ ACE Rapid Reaction Corps, including the head of operations, were unable to deploy to Macedonia with the remainder of their NATO colleagues. The delay was only for a few days, so while this had more of an embarrassing effect than a substantive one, it did demonstrate the internal political hurdles that the Clinton Administration had to overcome in order to support the Kosovo intervention. 
fell apart." ${ }^{29}$ This was a view that was echoed by Paddy Ashdown in his report to the British Prime Minister after a visit to the region in April 1999. ${ }^{30}$ Ultimately, the will of the Allied countries was carefully crafted to support the ground campaign both politically and militarily. An interesting observation is that consensus seemed to have been created more by a fear of NATO failure than by any firm agreement on what they were attempting to achieve. This lack of diplomatic and military coherence was recognized as a crucial issue at the time, and the intervention two years later in Macedonia was much better orchestrated as a result.

\section{Macedonia}

Macedonians of all ethnic groups maintained an uneasy cooperation throughout the early Balkan wars. There were grievances on both sides, but the political elite did little to address them. It should be no surprise that many ethnic Albanians took succor from "the collapse of Serbian power in Kosovo," 31 and began to advance their claims in a more violent manner. After a desultory and spasmodic couple of months of fighting in early 2001, violence flared up in several parts of the country. By early summer 2001 the ethnic Albanian National Liberation Army (NLA) had some 2000 members, and fighting around Arachinovo appeared to be on the verge of spiraling out of control. In the event, the international community - but particularly NATO and the EU-attempted to defuse the situation by active engagement. This engagement proved to be highly successful and, after a series of ceasefires in July and August, "international pressure finally led to the Macedonian and Albanian representatives in government signing what became known as the Ohrid [Framework] Agreement on 13 August 2001." 32

NATO's Mark Laity was intimately involved in events both as the Secretary-General's Special Advisor and then as his representative in the Cabinet of the Macedonian President. While stressing the importance of local context in Macedonia (as in all such scenarios), Laity felt that the lessons from NATO's intervention in Macedonia in 2001 could serve as a useful model of preemptive diplomacy. ${ }^{33}$ Perhaps the most important lesson he identified was that of early and high-level engagement. ${ }^{34}$ This lesson is something that has been echoed by others, including the NATO Secretary-General himself. ${ }^{35}$ It was, however, particularly evident that Lord Robertson and Javier Solana, the

29 Allin, NATO's Balkan Interventions, 61.

30 Paddy Ashdown, Swords and Ploughshares: Bringing Peace to the $21^{\text {st }}$ Century (London: Weidenfeld \& Nicolson, 2007), 6.

31 Gallagher, The Balkans in the New Millennium, 97.

32 Ibid., 107.

33 Mark Laity, Preventing War in Macedonia: Pre-Emptive Diplomacy for the $21^{\text {st }}$ Century, Whitehall Paper No. 68 (London: RUSI/Routledge, 2008), 76-91.

34 For example, see Kaufman, NATO and the Former Yugoslavia, 221; and Risto Karajkov, "Macedonia's 2001 Ethnic War: Offsetting Conflict - What Should Have Been Done That Was Not?" Conflict Security and Development 8:4 (December 2008): 451.

35 Lord George Robertson, "The Omaha Milkman Today: NATO's Transformation - An Agenda for a New Century," RUSI Journal 149:1 (February 2004): 45. 
EU/HR, invested considerable personal and institutional capital both in creating the necessary political space for those stakeholders ${ }^{36}$ who would resolve the crisis, as well as the freedom of maneuver for those NATO and EU officials who were acting as facilitators. It was a highly successful combination. Furthermore, it led to fast decision making on the basis of civil-military coherence and allowed the appropriate and speedy use of force. Perhaps as a codicil, however, is Laity's point that everything was nearly undone by the lack of a NATO information campaign within the country, which allowed a "bad media situation" to become significantly worse. ${ }^{37}$ Part of the problem was under-staffing of the NATO Press Information Center, or staffing with unqualified individuals (issues to be laid at the feet of the member states), as well as a rather rigid interpretation of a narrow KFOR Rear mandate.

\section{The Lessons of the Western Balkans}

Having analyzed all three NATO interventions in the Western Balkans, it would now be helpful to bring some of the overarching strands together. It should be self-evident that any military intervention also carries responsibilities for dealing with the aftermath: in effect, state-building. King and Mason make the point that "[p]eace deals should be oriented less to ending wars than to establishing a just and sustainable peace." ${ }^{38}$ This did not happen in Bosnia, nor did it in Kosovo. One could argue, however, that it did in Macedonia. Ashdown also argues cogently that not only should a state or an organization intervene as a very last resort, but that they also need to plan more for the subsequent peace than for the intervention. ${ }^{39}$ This includes, inter alia, the appropriate sequencing of certain tactical and operational activities:

- From the very first moment, the intervening force should dominate the security space. In Kosovo there was a security vacuum in a number of areas, which were filled by the KLA. The resultant grip they then exercised over both the population and the organs of state were never fully pried from their grasp. ${ }^{40}$ The key for NATO forces should always be to hold the field while a political solution is found. ${ }^{41}$

- The concept of security cannot be separated from that of human security. ${ }^{42}$

36 Such as the Macedonian President, Boris Trajkovski and the leader of the NLA, Ali Ahmeti.

37 Laity, Preventing War in Macedonia, 87.

38 King and Mason, Peace at Any Price, 257.

39 Ashdown, Swords and Ploughshares, 67-95.

40 The subsequent disarmament, demobilization, and reintegration (DDR) of the KLA were mandated in UNSCR 1244, and had the potential for serious difficulties. In the event, NATO handled this well, although its successor organization, the Kosovo Protection Corps (KPC), continued to pose concerns. See Nat J. Colletta, et al., Interim Stabilization: Balancing Security and Development in Post-Conflict Peacebuilding (Stockholm: SIPRI, 2008), 33-36.

41 Ashdown, Swords and Ploughshares, 76.

42 Marlies Glasius and Mary Kaldor, "A Human Security Vision for Europe and Beyond," in $A$ Human Security Doctrine for Europe: Project, Principles, Practicalities, ed. Glasius and Kaldor (London: Routledge, 2007), 6-8. 
Thus, the intervening forces must focus on applying the rule of law as quickly as possible, and must view it as an integral part of dominating the security space. As Friesendorf points out, UN civilian police officers were deployed very late in both Bosnia and Kosovo, and the burden of maintaining the rule of law had to be shouldered by reluctant NATO forces. Even then, individual military contingents responded in different ways, and with varying degrees of effectiveness and enthusiasm. ${ }^{43}$ It is a lesson that NATO and coalition forces continue to struggle with in Iraq and Afghanistan. It is, however, better enshrined in military doctrine than was previously the case, and use is now made of NATO gendarmerie-style forces when they are appropriate. ${ }^{44}$

- There is always a regional impact to any intervention or any crisis, and this needs to be taken into account from the start. For example, NATO has grouped all its operations and missions in the Western Balkans under one command in order to ensure overall coherence. This allowed a much more integrated and regional response to the Kosovo riots of March $2004 .{ }^{45}$

- The role of security sector reform (SSR) and defense institution building has been crucial to both state-building and peace-building in the Western Balkans. This issue is covered more fully later in this article.

- An integral aspect of SSR is striking an appropriate balance between capacity building (which sometimes creates a level of dependency) and local ownership. ${ }^{46}$ Ultimately, however, there will need to be a high level of local ownership in order to secure and embed the reform process. ${ }^{47}$

43 Cornelius Friesendorf, The Military and Law Enforcement in Peace Operations: Lessons from Bosnia-Herzegovina and Kosovo (Vienna/Berlin: LIT Verlag/DCAF, 2010), 90-95.

44 A short summary of the use of Italian Carabineri to train the Iraqi National Police can be found on the NATO Training Mission Iraq website, at http://www.jfcnaples.nato.int/ntmi/ information/other_projects.html. There is also a NATO Training Mission Afghanistan, which has a broader remit for both the Afghan Army and Afghan Police; see www.ntm-a.com.

During those riots the commander of Joint Force Command (JFC) Naples lobbied politicians and diplomatic staff across the region to help defuse the situation, and was also able to redeploy NATO forces from other Balkan missions to Kosovo. Details of the HQs under the command of JFC Naples can be found at www.jfcnaples.nato.int.

Brig. Gen. James Baxter, "Lessons of NATO Involvement in the Balkans," speech delivered at the conference "Securing Peace: NATO's Role in Crisis Management and Conflict Resolution," Brussels (16 October 2003); available at www.nato.int/cps/en/natolive/opinions 20530.htm? selectedLocale $=$ en.

47 There is some excellent literature on this subject, such as Laurie Nathan, No Ownership, No Commitment: A Guide to Local Ownership of Security Sector Reform (Birmingham: University of Birmingham, GFN-SSR, 2007); and Timothy Donais, ed., Local Ownership and Security Sector Reform (Zürich/Berlin: LIT Verlag/DCAF, 2008). 
- Economic uncertainty and poverty create instability and insecurity, and thus economic regeneration should be made an early priority in any intervention. ${ }^{48}$ After some delay NATO has learned this lesson, and this activity is included as a matter of routine as part of the missions of their Provincial Reconstruction Teams (PRTs) in Afghanistan. It is important to note, however, that NATO is not taking the lead in economic redevelopment, but is merely preparing the ground for the follow-on work of development agencies. ${ }^{49}$ Similarly, NATO has recognized "the crucial link between maintaining stability and delivering development aid to Afghanistan," and has produced a specific procurement policy to assist local actors. ${ }^{50}$ Notwithstanding NATO's progress in this area, they, along with the rest of the international community, still tend to inflate local salaries and can distort the local economy through their spending power. What happens is that well-qualified and educated people, who should be helping the host nation develop its own capacity, are seduced into highly-paid but low-value jobs with international organizations. Michael Ignatieff described this as "capacity sucking out." ${ }^{51}$ It is a difficult issue for all concerned, but all actors - both local and international — need to be mindful of the harm that can be done.

- The need to cooperate with other actors on a variety of different issues has been recognized by NATO in its interventions in the Western Balkans, and they have developed a "Comprehensive Approach" to ensure that such cooperation takes place. They have encountered a number of difficulties in translating the policy into sustainable action, a challenge that will be covered in more detail in a later section of this paper.

- Perhaps the most telling lesson that NATO is still grappling with, both in the Western Balkans and in Afghanistan, is, to use Ashdown's words, "at the end, do not wait until everything is as it would be in your country, but leave when the peace is sustainable." ${ }^{52}$ NATO still has a residual presence in all the countries where it has intervened. Closing down some of its missions must now be on the agenda.

48 Anthony Cleland Welch, "Achieving Human Security after Intra-State Conflict: The Lessons of Kosovo," Journal of Contemporary European Studies 14:22 (August 2006): 225-26; and Ashdown, Swords and Ploughshares, 80-84.

49 Some guidance in this field for the U.K.'s Stabilization Unit is contained in their Quick Impact Projects Handbook; available on a password-protected website at www.stabilisationonline.org/ edocs/ref_docs/qip_handbook.pdf.

50 See NATO Press Release, "Afghan First Policy-Supporting Afghan Economic Development," Press Release 048, 23 April 2010; available at www.nato.int/cps/en/natolive/official_ texts_62851.htm?mode=pressrelease.

51 Michael Ignatieff, “The Burden," New York Times Magazine (5 January 2003): 162; as quoted in Francis Fukuyama, State-Building: Governance and World Order in the TwentyFirst Century (Ithaca, NY: Cornell University Press, 2004), 139.

52 Ashdown, Swords and Ploughshares, 213. 
Many of the lessons above have not been entirely learned, nor have they been completely ignored. NATO's military structure has changed in order to meet current threats, including the creation of a more streamlined command structure and a Joint Analysis \& Lessons Learned Center (JALLC).$^{53}$ The individual nations' training standards have incorporated some of the hard-won experience of the Balkan wars, and lessons teased out over the past ten years are now being fed into the doctrine of some of the larger Allies ${ }^{54}$ as well as NATO's own doctrine. ${ }^{55}$ Although there have been setbacks, it could be argued that NATO's three major interventions in the Western Balkans each "came at an earlier stage and was therefore increasingly effective in saving lives and preventing overspill." 56

\section{Security Sector Reform and Democratic Development}

During the past fifteen years NATO has used its position as the world's pre-eminent collective security alliance to assist numerous countries in Eastern Europe-and in particular the Western Balkans - to transform their security sectors. This process has also been a point of entry to encourage a much broader range of reforms across the entire government sector in these states. These reforms have been linked to the Partnership for Peace (PfP) activities, but more specifically to the processes of NATO enlargement and the Membership Action Plan (MAP). This later program has used the conditionality of NATO membership as a highly effective lever to drive forward the reform agenda in transitional states. ${ }^{57}$ It has developed a series of thematic programs that offer practical assistance to partner countries (e.g., Partnership Action Plan-Defense Institution Building, or PAP-DIB). These have evolved over time in response to political demands for tangible evidence of progress in reforms, and have built upon lessons identified in the Western Balkans. ${ }^{58}$

We will now turn to the details of NATO's current engagement in the Western Balkans as they relate to security sector reform (SSR). Currently there are three NATO

53 See www.act.nato.int/content.asp?pageid=334.

54 See for example U.S. Field Manual 3-07 (Stability Operations); and the U.K. Joint Doctrine Publication 3-40 (Security and Stabilisation).

55 NATO Allied Joint Doctrine for Counterinsurgency (COIN) AJP-3.4.4 (Draft)

56 Robertson, "The Omaha Milkman Today," 45.

57 Dennis Blease, "NATO and SSR in the Western Balkans," paper presented on the panel "NATO and Defence Reform: Experiences in the Western Balkans and Beyond" at the conference "Towards a Whole of Government Approach to Security System Reform (SSR)," The Hague (9 April 2008).

58 For a more detailed treatment within the Western Balkans, see Milan Jazbeć, Security and Diplomacy in the Western Balkans (Ljubljana: IFIMES, 2007), 76-78. 
HQs in the Region (Sarajevo, ${ }^{59}$ Skopje, and Tirana), which exist to provide advice on defense reform and SSR to their respective host nations. Not only has their work been invaluable in embedding stability, but it has also traced a natural progression from NATO's original tactical missions in those countries. A Military Liaison Office was opened in Belgrade at the end of 2006. While its primary role is linked to operational matters, its secondary role is focused on reform and providing support to Belgrade's Defense Reform Group. ${ }^{60}$ KFOR still has a major tactical role in providing a safe and secure environment in Kosovo, but it now also has a role in assisting the Kosovar authorities in creating the new Kosovo Security Forces (KSF) and its concomitant ministry. ${ }^{61}$ The acceptance of these various roles in security sector reform throughout the region demonstrate that NATO has learned some lessons in how best to assist countries in the process of democratic development. Unfortunately, their approach remains inconsistent. In 2007, the Allies and the International Staff declined to provide a NATO Advisory Team in Podgorica after Montenegro's secession from Serbia. This was disappointing in that the Montenegrin government had specifically requested such assistance; its provision would have cost little, and could have resulted in considerable gains.

While NATO's International Staff can be congratulated on keeping the momentum of reform going over the past fifteen years, they would appear to have been less successful in weaving the various strands of reform together in a more holistic manner. In recent years most high-level meetings have publicly endorsed the priority of SSR, but they have still not produced a conceptual or policy framework for SSR. ${ }^{62}$ This is at variance with other major international actors such as the $\mathrm{EU}^{63}$ and the $\mathrm{UN},{ }^{64}$ which

${ }^{59}$ For a review of NATO HQ Sarajevo's role in the reform process, see Bruce McLane, "NATO Reform in Bosnia-Herzegovina," in Supporting Bosnia and Herzegovina: The Challenge of Reaching Self-Sustainability in a Post-War Environment, eds. Ernst Felberbauer, Predrag Jureković, and Frederic Labarre (Vienna: Austrian Federal Ministry of Defense, 2009), 67-76.

${ }^{60}$ See www.jfcnaples.nato.int/mlo/documents/mission.html.

${ }^{61}$ For more detail on these tasks, see www.nato.int/cps/en/natolive/topics_48818.htm.

${ }^{62}$ See, for example, NATO, "Riga Summit Declaration," Riga, Latvia (29 November 2006), paragraphs 9 and 12; available at www.nato.int/cps/en/natolive/official_texts_37920.htm? selectedLocale=en. See also NATO, "Final communiqué of the ministerial meeting of the North Atlantic Council held at NATO headquarters," Brussels (7 December 2007), paragraphs 4 and 16; available at www.nato.int/cps/en/natolive/official_texts_46356.htm? selectedLocale=en. See also NATO, "Bucharest Summit Declaration," Bucharest, Romania (3 April 2008), paragraphs 31-32; available at www.nato.int/cps/en/natolive/official_texts_ 8443.htm?selectedLocale=en. And NATO, "Strasbourg/Kehl Summit Declaration," Strasbourg/Kehl (4 April 2009), paragraph 30; available at www.nato.int/cps/en/natolive/news _ 52837.htm?selectedLocale=en.

${ }^{63}$ The EU has two frameworks: one for the Council (see Council of the European Union, "EU Concept ESDP Support to Security Sector Reform," Doc 12566/4/05 REV 4, 2005) and one for the Commission (see COM(2006) 253 final, SEC(2006) 658, Brussels [24 May 2006]). 
have made significant strides in developing their approaches to SSR. NATO has made spasmodic attempts to rectify this anomaly, but there has been no consensus among the Allies for such action. ${ }^{65}$ So, while NATO's contributions to SSR and defense reform in the Western Balkans have been considerable and widely praised, ${ }^{66}$ they continue to evolve in a suboptimal fashion.

\section{A Comprehensive Approach}

Another key theme that has emerged from NATO's involvement in the Western Balkans has been the requirement to deal with a variety of international organizations as well as a number of non-NATO countries. ${ }^{67}$ Recent literature is replete with references to the need for cooperation, ${ }^{68}$ and much of it stresses specifically the need for NATOEU cooperation. ${ }^{69}$ In describing best practices for interventions, Ashdown goes a stage further and stresses the need to "[u]nderstand the importance of the international community effort of coordination, cohesion and speaking with a single voice." ${ }^{70}$ The last point is especially important, but it often presents a Sisyphean challenge in most postconflict scenarios. Experience on the ground shows that during stabilization and postconflict missions there are a plethora of actors, engaged in a variety of elements of

64 United Nations SG/SM/11564 SC/9328 (2008). For press release, see www.un.org/News/ Press/docs/2008/sgsm11564.doc.htm.

65 Several draft papers on SSR have been produced by the Defense Planning and Policy division of NATO's International Staff. In the event, one nation has taken the view that SSR should be under the purview of the EU, and that NATO should restrict its activities to defense reform, which runs counter to the conventional wisdom of the need for a holistic approach. This outlying view has only served to accentuate the difficulties of managing change where consensus is always needed.

66 See, for example, Marina Caparini, "Security Sector Reconstruction: Western Balkans," in Reform and Reconstruction of the Security Sector, eds. Alan Bryden and Heiner Hänggi (Münster: LIT Verlag/DCAF, 2004), 167-68.

67 An interesting account of the U.K. MOD's perspective regarding the Bosnia and Kosovo conflict can be found in: British Ministry of Defence, "The Comprehensive Approach: Joint Discussion Note 4/05" (2005), 1-1; available at www.mod.uk/NR/rdonlyres/BEE7F0A4C1DA-45F8-9FDC-7FBD25750EE3/0/dcdc21_jdn4_05.pdf.

68 See, for example, Sheila Coutts and Kelvin Ong, "Managing Security Sector Reform," presentation at the EUISS conference "The UN, the EU, NATO and Other Regional Actors: Partners in Peace?" Paris (11-12 October 2002), 12-14. See also Edward Boanas, "Crossing the Fault Line: Coordinating Multilateral Security Sector Reform Engagements in Post-Conflict Countries," Journal of Security Sector Management 3:3 (June 2005); available at www.ssronline.org/jofssm/issues/jofssm_0303_boanas_faultlines.pdf?CFID=247093\&CFTO $\mathrm{KEN}=85505669$.

69 See, for example, Alex Dowling, "Executive Summary," in Security Sector Reform in South East Europe: From a Necessary Remedy to a Global Concept, eds. Anja Ebnöther, Ernst Felberbauer, and Mladen Staničić, proceedings of the $13^{\text {th }}$ Workshop of the Study Group on Regional Stability in South East Europe (Vienna: Austrian National Defense Academy/ DCAF, 2007), 159.

70 Ashdown, Swords and Ploughshares, 213. 
conflict resolution, state-building, and SSR, all with different mandates, different funding streams, and different approaches. An actor's decisions in one country will often have an impact on a neighboring country. Some actors therefore take a regional approach, while others maintain a global perspective. Some focus on governmental oversight, others on police reform. Stephanie Blair uses the interesting analogy of weaving the strands of a rope in her treatise on Kosovo, with its various strands (sectoral activities) and threads (actors) all interdependent and interwoven to form a strong rope (and thus a sustainable peace). ${ }^{71}$ Her analogy is completely germane to NATO's experience in the post-conflict arena.

Denmark, ${ }^{72}$ among other nations, was signally influential in persuading NATO to begin developing its own "Comprehensive Approach" at the Riga Summit in November $2006 .^{73}$ The summit declaration highlighted the need for NATO to coordinate with specific organizations, especially "the activities of the UN, EU and the OSCE to build governance and support reform." 74

The process of delivering on NATO's Comprehensive Approach remains difficult, however, for many reasons, not least of which is that NATO cannot demand cooperation from other autonomous actors. Empirical evidence would seem to suggest that cooperation is easier where there are shared interests and values, such as between NATO and the EU. The declaration from NATO's Riga Summit contained no less than six separate references to NATO and EU cooperation or shared values. ${ }^{75}$ Again, the public utterances of the two leaderships have generally been supportive of this collaboration. Javier Solana stated that, "as far as NATO is concerned, we will in the coming years be literally working side by side in the security field." ${ }^{76}$ And as Jaap de Hoop Scheffer said, "in the Balkans, NATO and the EU have worked together very effectively, and I am optimistic about our ability to do so again." 77 Similarly, their respective policy documents are broadly positive about the need for a close partnership.

71 Stephanie Blair, "Weaving the Strands of the Rope: A Comprehensive Approach to Building Peace in Kosovo," Centre for Foreign Policy Studies, Dalhousie University, Halifax, Nova Scotia (2002), 77. (Blair attributes the analogy to the then Lt. Gen Mike Jackson, the first COMKFOR.) Paper is available at http://centreforforeignpolicystudies.dal.ca/pdf/weaving thestrandsoftherope.pdf.

72 Brooke Smith-Windsor, "Hasten Slowly: NATO's Effects Based and Comprehensive Approach to Operations," NATO Research Paper 38 (Rome: NATO, July 2008); available at www.ndc.nato.int/research/series.php?icode $=1$.

73 NATO, Riga Summit Declaration (29 November 2006), paragraph 10; available at www.nato.int/docu/pr/2006/p06-150e.htm.

74 Ibid., end of paragraph 9.

75 Ibid.; references are contained at paragraphs 6, 9 (twice), 23, 23 (twice).

76 Javier Solana, "From Dayton Implementation to European Integration," in Historic Change in the Balkans, special issue of NATO Review (Winter 2004): 9; available at www.nato.int/ docu/review/2004/issue4/english/art2.html.

77 Jaap de Hoop Scheffer, "NATO and ESDP: Forging New Links," keynote address at the Security and Defense Agenda Conference, Brussels (8 June 2007), 2; available at www.nato.int/docu/speech/2007/s070608a.html. 
It must be acknowledged, however, that there can sometimes be a gap between public pronouncements and reality. For example, the organizations' cooperation within "Berlin Plus" has not been exactly flawless, but it has achieved some success. During the first ESDP mission in Macedonia (Operation CONCORDIA in 2003) and in Bosnia and Herzegovina (Operation ALTHEA in 2004), NATO handed over tactical missions to the EU. The focus at the tactical level on delivery rather than on theology, particularly during the ALTHEA mission, meant that the practical points of coordination could be worked upon and developed to a stage where they would be relatively seamless in the future. Furthermore, practical cooperation in the field between NATO and EU political staffs tends to work well. ${ }^{78}$ It does therefore seem to indicate that the two organizations are learning the lessons of the Western Balkans and can break down some of the institutional barriers on the ground and deliver mission success. But more success would be better.

\section{A Political Agenda for a Political Alliance ${ }^{79}$}

For a number of years now, there has been a circular argument underway about whether NATO is merely a defense alliance or something more. Jamie Shea wrote NATO 2000 in 1990, as he sought to chart NATO's path to the turn of the millennium, complete with its challenges, risks, uncertainties, and opportunities. While he did not predict the dissolution of Yugoslavia, he did predict the desire of many Eastern European countries to move closer to both NATO and the EU. He also recommended a series of engagements (political, economic, and cultural) that still resonate today. The bottom line of his thesis, however, was the need for NATO to adopt an essentially "political" agenda, and that by the end of the twentieth century "it will be seen as the primary clearing house of Western policy-making ... [and] ... manage transatlantic relations." 80

At the time there were many who doubted this vision of the future. But it was the combination of a program of cooperation with Eastern European countries as part of the enlargement policy and NATO's military involvement in the Western Balkans that forced that political vision to the fore. Such a transformation was not without its difficulties, as domestic considerations as well as a fractious internal dynamic between the U.S. and the European member states initially hindered consensus. ${ }^{81}$ It is to the eternal credit of the Cold War version of NATO, however, that it did transform itself into an

78 See, for example, Karl-Heinz Rambke and Sebastian Keil, "EU-NATO Cooperation in PostConflict Reconstruction," in The European Union and Security Sector Reform, eds. David Spence and Philipp Fluri (London: John Harper Publishing, 2007), 270; and Ambassador Michael Sahlin, "Regional Security-Enhancing Organizations," paper presented at "Adriatic 3: Towards NATO Membership, Perspectives and Challenges," Marshall Center Conference for Adriatic Charter Countries, Skopje, Macedonia (15 March 2005), 2.

79 Taken from the title of Jamie Shea, NATO 2000: A Political Agenda for a Political Alliance (London: Brassey's, 1990).

80 Shea, NATO 2000, 58.

81 Kaufmann, NATO and the Former Yugoslavia, 126-27. 
alliance that could make hard and difficult decisions, providing the military might that was required to produce political outcomes, as well as an impressive level of diplomatic and military coherence.

By the time that the sixtieth anniversary of NATO was celebrated at the Strasbourg/ Kehl Summit in 2009, the idea that NATO was a political alliance was no longer in question, as evinced by the words of the Norwegian Defense Minister: "I therefore believe that the Alliance should be regarded as more than just a 'tool box' only containing military capabilities. ... NATO has however illustrated time and again that it also is a political organization." 82

\section{Conclusion}

There are some commentators, like Mark Webber and James Sperling, who argue that NATO's record is mixed, with "a crisis recognized, acted upon in a less than optimum manner, and giving point to a continuing process of change." ${ }^{83}$ But this is only half the picture. The body of evidence supports the assertion that NATO has undergone a fundamental process of transformation over the past fifteen years, with much of that change having been brought about by learning from its experiences conducting military missions in the Western Balkans. In some areas it has not learned very well, and in other areas it has only learned slowly. Although the picture is not perfect, the trend is definitely upwards.

Of particular note is the way that NATO has overcome significant political and military hurdles when it has been challenged; the way it has opened its doors to Eastern European countries in the process of enlargement, including from the Western Balkans; the way it has used the conditionality of NATO membership (often in concert with the EU and its membership criteria) in order to drive the reform process; and the way it has begun its political and practical engagement with other international actors in the Comprehensive Approach. There is much to commend. It is worth leaving the last word to Dana Allin, who expressed the view that NATO had learned from its military interventions in the Western Balkans, and that the Alliance's "'learning curve' is discernible in the record of early failures and later successes." ${ }^{84}$

82 Anne-Grete Strøm-Erichsen, "NATO in the $21^{\text {st }}$ Century," speech at The Leangkollen Seminar (2 February 2009); available at http://www.regjeringen.no/en/dep/fd/whats-new/Speechesand-articles/minister/forsvarsminister-stroem-erichsen/2009/nato-in-the-21st-century.html?id= 544547.

83 James Sperling and Mark Webber, "NATO: From Kosovo to Kabul," International Affairs 85:3 (2009): 500 .

84 Allin, NATO's Balkan Interventions, 91. 


\section{Bibliography}

Afghan First Policy—Supporting Afghan Economic Development. NATO, 2010.

Allin, Dana. NATO's Balkan Interventions. London: International Institute for Strategic Studies, 2002.

Ashdown, Paddy. Swords and Ploughshares: Bringing Peace to the 21st Century. London: Weidenfeld \& Nicolson, 2007.

Baxter, James. Lessons of NATO Involvement in the Balkans. Brussels: conference "Securing Peace: NATO's Role in Crisis Management and Conflict Resolution", 2003.

Blair, Stephanie. Weaving the Strands of the Rope: A Comprehensive Approach to Building Peace in Kosovo. Halifax, Nova Scotia: Centre for Foreign Policy Studies, Dalhousie University, 2002.

Blair, Tony. Doctrine of the International Community., 1999.

Blease, Dennis. "NATO and SSR in the Western Balkans." In Towards a Whole of Government Approach to Security System Reform (SSR). Hague, 2008.

Boanas, Edward. "Crossing the Fault Line: Coordinating Multilateral Security Sector Reform Engagements in Post-Conflict Countries." Journal of Security Sector Management 3, no. 3 (2005).

Bucharest Summit Declaration. Bucharest, Romania: NATO, 2008.

Caparini, Marina. "Security Sector Reconstruction: Western Balkans." In Reform and Reconstruction of the Security Sector, 167-68. Münster: LIT Verlag/DCAF, 2004.

Colletta, Nat J.. Interim Stabilization: Balancing Security and Development in PostConflict Peacebuilding. Stockholm: SIPRI, 2008.

Deutschman, Alan. Change or Die: The Three Keys to Change at Work and in Life. New York: HarperBusiness, 2007.

Donnelly, Christopher. "Security in the 21st Century: New Challenges and New Responses." In NATO and New International Relations, 24-26. Zagreb: Atlantic Council of Croatia \& Political Culture Publishing and Research Institute, 2004.

Dowling, Alex. "Executive Summary." In Security Sector Reform in South East Europe: From a Necessary Remedy to a Global Concept, 159. Vienna: Austrian National Defense Academy/ DCAF, 2007.

EU Concept ESDP Support to Security Sector Reform. Council of the European Union, 2005.

Evans, Gareth. The Responsibility to Protect: Ending Mass Atrocity Crimes Once and for All. Washington, D.C.: Brookings Institution Press, 2008.

Final communiqué of the ministerial meeting of the North Atlantic Council held at NATO headquarters. Brussels: NATO, 2007. 
Friesendorf, Cornelius. The Military and Law Enforcement in Peace Operations: Lessons from Bosnia-Herzegovina and Kosovo. Vienna/Berlin: LIT Verlag/ DCAF, 2010.

Gallagher, Tom. The Balkans in the New Millennium: In the Shadow of War and Peace. London: Routledge, 2005.

Glasius, Marlies, and Mary Kaldor. "A Human Security Vision for Europe and Beyond." In A Human Security Doctrine for Europe: Project, Principles, Practicalities, 6-8. London: Routledge, 2007.

Heinbecker, Paul. "Kosovo." In The UN Security Council: From the Cold War to the 21st Century, 537. Boulder, CO: Lynne Rienner, 2004.

Ignatieff, Michael. "The Burden." New York Times Magazine (2003): 162.

Jazbeć, Milan. Security and Diplomacy in the Western Balkans. Ljubljana: IFIMES, 2007.

Karajkov, Risto. "Macedonia's 2001 Ethnic War: Offsetting Conflict - What Should Have Been Done That Was Not?" Conflict Security and Development 6, no. 4 (2008): 451.

Kaufman, Joyce. NATO and the Former Yugoslavia: Crisis, Conflict, and the Atlantic Alliance. Lanham, MD: Rowman \& Littlefield, 2002.

King, Iain, and Whit Mason. Peace at Any Price: How the World Failed Kosovo. Ithaca, NY: Cornell University Press, 2006.

Laity, Mark. Preventing War in Macedonia: Pre-Emptive Diplomacy for the 21st Century. London: RUSI/Routledge, 2008.

Malcolm, Noel. Kosovo: A Short History. New York: Harper Perennial, 1999.

McLane, Bruce. "NATO Reform in Bosnia-Herzegovina." In Supporting Bosnia and Herzegovina: The Challenge of Reaching Self-Sustainability in a Post-War Environment, 67-76. Vienna: Austrian Federal Ministry of Defense, 2009.

Meyer, Christopher. Getting Our Way: 500 Years of Adventure and Intrigue: the Inside Story of British Diplomacy. London: Weidenfeld \& Nicolson, 2009.

Nathan, Laurie. No Ownership, No Commitment: A Guide to Local Ownership of Security Sector Reform. Birmingham: University of Birmingham, GFN-SSR, 2007.

NATO's Agenda: Key Issues Facing the Bucharest Summit In RUSI Occasional Paper., 2008.

Owen, David. Balkan Odyssey. New York: Harcourt Brace, 1995.

Rambke, Karl-Heinz, and Sebastian Keil. "EU-NATO Cooperation in Post-Conflict Reconstruction." In The European Union and Security Sector Reform, 270. London: John Harper Publishing, 2007.

Rasmussen, Anders Fogh. NATO Transformation and Reform Vital to Facing New Challenges., 2010. 
Riga Summit Declaration. NATO, 2006.

Robertson, Lord George. "The Omaha Milkman Today: NATO's Transformation - An Agenda for a New Century." RUSI Journal 149, no. 1 (2004): 45.

Scheffer, Jaap de Hoop. NATO and ESDP: Forging New Links. Brussels: Security and Defense Agenda Conference, 2007.

Shea, Jamie. NATO 2000: A Political Agenda for a Political Alliance. London: Brassey's, 1990.

Smith, Rupert. The Utility of Force: The Art of War in the Modern World. London: Penguin Books Ltd., 2005.

Smith-Windsor, Brooke. Hasten Slowly: NATO's Effects Based and Comprehensive Ap-proach to Operations In NATO Research Paper. Rome: NATO, 2008.

Solana, Javier. From Dayton Implementation to European Integration In Historic Change in the Balkans. NATO Review, 2004.

Sperling, James, and Mark Webber. "NATO: From Kosovo to Kabul." International Affairs 85, no. 3 (2009): 500.

Strasbourg/Kehl Summit Declaration. Strasbourg/Kehl: NATO, 2009.

Stremlau, John. People in Peril: Human Rights, Humanitarian Action and Preventing Deadly Conflict. Washington, D.C.: Carnegie Commission on Preventing Deadly Conflict, 1998.

Strøm-Erichsen, Anne-Grete. NATO in the 21st Century. Leangkollen Seminar, 2009.

The Comprehensive Approach: Joint Discussion Note 4/05. British Ministry of Defence, 2005.

Trapans, Dr. Jan Arveds. Security Sector Reform in Central and Eastern Europe: The Work of Civilians and the Military. Groningen: Centre for European Security Studies, 2000.

Welch, Anthony Cleland, Sokol Kondi, Dana Stinson, and Michael von Tangen Page. Kosovo Internal Security Sector Review. Pristina: United Nations Development Program, 2006.

Welch, Anthony Cleland. "Achieving Human Security after Intra-State Conflict: The Lessons of Kosovo." Journal of Contemporary European Studies 14, no. 22 (2006): 225-26. 